\title{
AN ANALYSIS OF THE TRANSLATION PRODUCTS FROM ENGLISH TEXT INTO INDONESIAN LANGUAGE
}

\author{
Andi Asri Jumiaty ${ }^{1}$ \\ Corresponding e-mail: jandiasri@yahoo.co.id \\ Universitas Muhammadiyah Makassar, Makassar, Indonesia
}

\begin{abstract}
This research found out the students' error in translating English text into Indonesian language at Muhammadiyah University of Makassar. This research investigated students' ways in translating and understanding the meaning of the text translated from English to Indonesian. A descriptive analysis was used in this research with the population was consisted of 107 students and applied purposive sampling technique and the chosen 60 students were taken as samples. The data was in the form of translation test. The result of the data analysis showed that the students' error types in translating English text into Indonesian were $81.6 \%$ generated translation was a literal translation and was 11 out of 60 students, or about $18.4 \%$ used the general translation from mistranslation or lexical meaning. And also it was found out that the students' error in lexical meaning. And there were $43 \%$ which has translated in general translation errors. This analysis was very useful for the teacher and students. It helped the students to know their weaknesses and difficulties in translating English text into Indonesian. It can be concluded that the students are directed to learn more and practice to translate about English text into Indonesian language.
\end{abstract}

Keywords: Pre-Service Teachers, Teaching Methods, Translation Products, Indonesian language

\section{INTRODUCTION}

English is the international language where English is the language of unifying the various nations. It has become a regular thing, if a person should be able to understand and to speak in English and to be able to communicate, we were able to compete with the development of language in the world. Because English is one of the unifying language of various countries in the world.

In the English language, there are four skills that become a reference, namely speaking, listening, reading and writing. Each skill has its field, as in speaking and reading there are many aspects that must be considered. Such as pronunciation, structure, grammar, syntax and vocabulary Also. In writing skill, there is translation.

Fakultas Keguruan dan Ilmu Pendidikan

Universitas Bosowa Makassar
To master the four skills we must master also sub skills such as grammar, vocabulary, and pronunciation. But in this case, it is very important to know how to translate one language to another language. The language we use is very different from English in other countries, and to be able to communicate with both the required learning to master how to translate.

Translation is an operation perform on languages like a process of substituting a text in one language for a text on another, translation must make use of a theory of the language, general linguistic theory. Translating is a skill that must be master to be able to understand the language of various countries, and in order to understand how to communicate well. Translating is an attempt to re-create the message in the source 
language into the target language by replacing naturally and can be understood by others. Translating is essentially a form of writing changes in different words and meaning both orally and writing.

Regardless of one's profession, there must be trouble in the profession even teach they maybe only minor difficulty, but still there are difficulties as well as an English translator professional. Actually there are some difficulties in the process of translation, but, certainly every problem has a solution. Here are some problems that often occur in translating.

Translation is a difficult job to do because it needs great effort and full attention of the translator in order to convey the message and the meaning of the sentences of the sources language. By remembering the difficult of the translation, the translators have to know all these aspects must be mastered by translator has to know the same aspect of the language. According to the Wills (1982 : 112) says that translation is a procedure which learn from a written source language text to an optimally equivalent target language text and requires the syntactic, semantic, stylistic, and text pragmatic comprehension by the translator of the original text. Catford (1965:20) states that translation may be defined as follows : the replacement of textual material in one language (SL) by equivalent textual material in another language (TL). Hanafi (1986: 26 ) stated translation is the replacement of text in the source language (SL) by semantically and pragmatically equivalent text in the target language (TL).

In this study, the term of translation refers to students transferring the language of English text into Indonesian. Newmark (1981:7 ) states that translation is an attempt to replace a written message and/or statement in one language by the same message and/ or statement in another language. As a means of communication, translation is used for multilingual notices or purposes. According to Vinay and Darbelnet (1995), there are two general categories of translating, namely 'direct' and 'oblique'. These two categories include seven strategies which are 'borrowing', 'calque', 'literal translation', 'transposition', 'modulation', 'equivalence' and 'adaptation'.

Because of the dramatic evolution of the professional translation industry, there are currently new terms and words being used to describe translation service specializations that don't fall under general categories like human translation or machine translation. This article intends to serve as a brief guide of sorts to some of the more common and basic of these recently coined expressions. Here are just some of them: (Choliluddin, 2002 ).

a) General Translation: The simplest of translation types, a general translation allows a translator quite a lot of leeway because its source material mostly uses layman terms and ordinary, everyday speech. There's no need to understand special terminologies, and most translation work fall into this particular type.

b) Legal Translation: As one of the more complex and complicate professional translation types out there, legal translation is best describe as the translation of treaties, contracts, and many other legal documents. A translation service is responsible for both understanding politico-legal and socio-cultural context behind a legal text and translating it in such a way that a target audience with a different cultural/political/societal background could readily understand. Only a human translation agency that knows both source and target cultures could pull a decent legal translation job off. Nevertheless, even specialists like 
this tend to use professional legal assistance as well, because one simple slipup or mistranslation of a contract's passage could lead to disastrous consequences.

The problem is that we often do not understand the purpose of the translation when the translation goal is to understand a text. Additionally, mistranslate little can be wrong. And intent submit does not agree. A further problem that often occurs in translating English is their ambiguity problem. This can occur in specific vocabulary and structure of a particular language so that we have difficulty in its formulation.

How to overcome the problems in the translation is to interpret the word by words first. And a professional translator should have capability to independent, and sometimes takes a long time. But at least we understand the meaning to be delivering by the translator to us.

Based on the background above, who the researcher formulated problem statement as follow:

1. What types of translation results for English into Indonesian do the second year students make?

2. What kinds of errors based on the standardized indication do the students make in their translation results?

In this world, language translation industry has been described using the terms of Globalization, Internationalization, and Translation. Within all these importing and exporting transaction and translator are transferring manuals, and documents also.

Depending in other country, have much different language as words may convey different meanings depending on the location that they are used. Mistranslating the word or meaning may become offensive, and some of the literal translations are not always correct. Therefore, keeping the meaning and the real message from the source text in the language translation process becomes more that a science.

This purposes was so diverse, the texts so different and the receptors so varied that one can readily understand how and why many distinct formulations of principles and practices of translation have been proposed. All who have written seriously on translating agree that translators should know both the source and the receptor languages should be familiar with the subject matter, and should have some facility of expression in the receptor language.

In an analysis of the types of interlingua communication involved in translating, one must described the role of the source as a combination of the intens of the primary source, the author and the secondary source, the translator himself. Accordingly, these purposes was best described in their relation to the three basic elements in communication with which each one is characteristically as associated.

After treating the communication factors of message, source, receptors and medium, brief consideration must be given to some of the practical and theoretical issues that have arisen in the development of translation theory: $(1)$ the limits of translatability ( 2 ) evaluation of translations and ( 3) translating as an art, a skill, or a science. The final section of this chapter is devoted to the analysis of the various theories in terms of the principal bases involved, namely, philogical, linguistic and sociolinguistic.

The word "error" entails different meanings and usage relative to how it is conceptually applied. The concrete meaning of the Latin word "error" is "wandering" or "staying" unlike an illusion, an error or a mistake can sometimes be dispelled through knowledge (knowing that one is looking at a mirage and not at real water does not make the mirage ( disappear). Also, an "error" is a deviation from accuracy or correctness, a mistake, as in action / speech. His speech 
contained several factual errors. Also, error is a moral offense wrong doing. Error is the condition at believing what is not true; in error about date.

In Kamus Inggris - Indonesia, error means "Kesalahan, kekeliruan dalam caracaranya bekerja / tindak - tanduknya. (1987;218). There are 5 (five) parts of a brief view of error analysis. They are the meaning of error analysis, the source of error, the types of errors, the practical uses of error analysis and the methodology of error analysis

\section{METHODOLOGY}

The writer uses a descriptive method, where the data was collect some references from many resources and gave the test after class about translating some sentences from English into Indonesian. It aim to described and analyse the error of the students in translating English into Indonesian by the students English Education of Makassar Muhammadiyah University. The variable in this research was to know the types of translation ability in English text into Indonesian and kinds of translation errors. The indicators of translation types in translating English text into Indonesian was literary of translation and kinds of translation error was lexical meaning in translating English text into Indonesian. To see the translation products, the instrument of the research gave the test. The test aimed to know the products that the result in translating English into Indonesian. The test was found out the data about the translation result. To get the data results of the study, the researcher gave an English text form of descriptive text and contains eight paragraphs and seven sentences. Then, the researcher gave the text for the students and had to translate the English text into Indonesian. Researchers gave the time for 60 minutes to translate. In addition, had to the students translate English text into Indonesian, the researchers collected the text and then gave a score for the number of errors and the results obtained from translating the text.

\section{FINDINGS AND DISCUSSION}

\section{Findings}

This part discusses abut the result findings of the text that give for the students which is based on the research questions. These research question are: What types of translation results for English into Indonesian do the students in the second year make and What kinds of errors based on the standardized indication do the students make in their translation results?". So, to know the answer from the research question, the researcher gives the text in one paragraph (English Text).

Researchers give one text English into Indonesian. The students must answer all the questions give by researchers and students understand the meaning of words in the text. So, according to the students translating word by word. To get the results from an error in interpreting the meaning, and the translation is done by the students, the researchers make the following of the table.

Table 1 Types of translation results made by the students

\begin{tabular}{ccc}
\hline Types of & Quantity & Percentage (\%) \\
Translation & & 81,6 \\
Literal & 49 & 18,4 \\
$\begin{array}{c}\text { Translation } \\
\text { General } \\
\text { Translation } \\
\text { Total }\end{array}$ & 11 & 100 \\
\hline
\end{tabular}

In this study, there are several types of translating the text general translation, literal translation, and commercial translation, administrative and legal translation. But, the researchers only get two types of translation, the general and the literal translation. generally the result of translating English text into Indonesian using a literal translation is the greatest compared to general translation, such as block in the 
table. The table shows that there are the students products in translating English text into Indonesian and the researcher has found some students' products in types of translation; they are Literal and General Translation.

Based on the table above, it can be seen that the translation type of the student is the literal translation. Most of the students have translated the text into Indonesian by using literal translation, and there are 49 of the 60 samples, or about $81.6 \%$ generated translation was a literal translation. While students who translated the general translation was 11 out of 60 samples or about $18.4 \%$.

Table 2 Translation errors based on Lexical item made by the students

\begin{tabular}{|c|c|c|c|}
\hline No. & $\begin{array}{c}\text { Kinds of } \\
\text { Errors }\end{array}$ & Quantity & $\begin{array}{c}\text { Percentage ( } \% \\
\text { ) }\end{array}$ \\
\hline 1. & $\begin{array}{l}\text { Lexical } \\
\text { Items }\end{array}$ & 677 & 57 \\
\hline \multirow[t]{2}{*}{2.} & General & 511 & 43 \\
\hline & Total & 1188 & $100 \%$ \\
\hline
\end{tabular}

This part the researcher would like to explain the result of data analysis obtains by the students through the items of text.

In this section, researchers explain translating error make by the students in the English language text translate into Indonesian. From 60 total samples into the study, there are 34 students or about $56.6 \%$, which is translate it means fair in a literal translation errors. And there are 26 of 60 total samples or approximately $43.4 \%$, which is translate it means poor in general translation errors. The data showed that there are $43,4 \%$ sample or products have an error translate, it means poor in translating the text.

In other researcher, the analysis of data collected through the test. The researcher found that they translated the text word by word and using dictionary. And also

Fakultas Keguruan dan Ilmu Pendidikan Universitas Bosowa Makassar the students have low vocabulary mastery. They difficulties to choose the lexical meaning that were translating. Besides that, the researcher found that some problems the students uninterested to learn English and especially in translating English text..

\section{Discussion}

In this part, the researcher would like to present the discussion of the result in data analysis. This discussion showed the products of the students in translation especially in translating English text into Indonesian. Based on the result of data analysis and the text above, the researcher found out the error and types of translation made by the students to translate English text as a follow:

1. Most of the students were not able to translate English text into Indonesian language. In this case, they can't translate the text like as the original language.

2. Some of the students translated the sentence or the paragraph using the dictionary to know the meaning of the sentence. But, the students didn't know what is the real meaning if they not using the dictionary. It made them translated word by word and the meaning is not complete.

3. Some of the students translate English text into Indonesian word by word. So that the translation was not correspond with the meaning of the text. Even though they used a dictionary, but they did not understand the text perfectly.

4. The researcher found several sentences of the students' errors meaning in translated the text.:

- My mother got me ready for school then I had to wait for her to brush my hair and place every strand in just the perfect position. Errors : Ibu saya membuat saya siap ke sekolah kemudian saya harus menunggu dia untuk 
mengikat rambut saya dan menempatkan setiap helainya dalam kesempurnaan.

- I had to show her my shoes that I had cleaned the night before and my school bag had to be neatly put on my shoulder before I could get near the door.

Errors : Aku harus menunjukkan padanya sepatu saya, bahwa saya dimalam sebelumnya, dan tas sekolah saya telah harus rapid an dikenakan dibahu sebelum saya dekat pintu.

- The playground would be full in the summer and the noise would make me want to rush into the yard and get into a good game of football before the bell went.

- Errors : Taman bermain kami penuh dimusim panas dan sangat ribut sehingga yang bermain sepak bola masuk karena bunyi bel.

\section{CONCLUSION}

Based on the data analysis in the previous chapter, the researcher would like to present the conclusion is most of the students who translate the English text into Indonesian use literal translation, because most of them still have the lack of vocabulary mastery and their knowledge in translating is low and for educator/lecturer give some varieties activity in translating English text. So that the students' will have experience in translating English text.

\section{ACKNOWLEDGEMENTS}

Andi Asri Jumiaty is lecturer in English Education Department, Teacher Training and Education Faculty, Makassar Muhammadiyah University. She is teaching English Skill such as Translation, Reading, Structure and English Pronunciation. Now, she is a student of English Education Department Post Graduate Program at State
University of Makassar. This research sponsored by LPDP as BUDI DN LPDP Awardee 2016.

\section{REFERENCE}

Afwan, W. (2015).The Analysis of Students' Grammatical Error in Indonesia English Translation by using descriptive text at the second year students' in SMA Negeri 1 Majene.

Baker. M.(1992). In other word a course book on translation. London: Routledge

Bassnet - Mc.Guire, Susan.(1980). Translation Studies. New York: Methuen \& Co,Ltd.

Bassnet.Susan.(1991). Translation Studies. London and NewYork : Routledge.

Bell. Roger.T.(1991).Translation and Translating: Theory and Practice. UK. Longman.

Choliludin. (2002). The teaching of Making Idiomatic Translation.

D Jamil. Burhan Elrosyi. (2013). A Transation Analysis of English Phrasal Verb In Endless Night Novel and ITS Translation. School of teacher training and education Muhammadiyah University of Surakarta.

Darma, (2015) The difficulties in translating Indonesian into English and English into Indonesian encountered by the fifth semester students. Thesis :Muhammadiyah University of Makassar.

Echols, M. John \& Hassan Shadily. (2000). KamusInggris-Indonesia. Jakarta: PT Gramedia

Ensiklopedi Sastra Indonesia. (2004). Bandung: Titian Ilmu

Hornby, A S. 2005. Oxford Advanced Learner's Dictionary. New York: Oxford University press.

Larson, M. L. (1984). Meaning Based Translation (A Guide Cross- 
Language Equivalence). New York: University Press of America.

Mataram, (2010). The effect of English Glossary to the students ability in translating English texts into Indonesian.

Newmark, P. (1981). Approaches to Translation. Oxford: Pergamon Press.

Newmark, P. (1988). A Textbook of Translation. London: Prentice Hall International.

Nugraha, Sitti Surya. (2015). An Analysis of Translation Error of short story at the second year students of SMA Muhammadiyah 7 Makassar.

PPL II. ( 2013 ). Errors Analysis of Students Translation of English Text Into Indonesian at the Eight Grade of Mts 46 Banjarmasin, 2014

Perkasa, G. H. (2006). An Analysis of Methods and Procedures of Translation in Toyota Warranty and Service Booklet.Unpublished Paper. Bandung English Department. Indonesia University of Education.

Safakum. Dhevyosyanny Riezky. (2014). An Analysis of Translation Equivalence Found In SubtittleOf Abraham Lincoln: Vampire Hunter Movie. Presented to Muria Kudus University in Partial Fulfilment of the Requirements for completing the Sarjana Program in The English Education Department.
Samir H. Ali I.Abouzar K.(2016) "Chicks Love it" "It's not Ha-wee-wee": Subtitling Strategies in Translation of Humor from English into Persian. Mediterranean Journal of Social Sciences.Vol 7, No 4. 593600.doi:10.5901/mjss.2016.v7n4p5 93

Setyasih, Beti Sari. (2007). A Translation Analysis of Colloquia 1 Expression in the Film Harry Potter and the Prisoner of Azkaban.Undergraduate Thesis. English Department, Faculty of Letters and Fine Arts. UNS. Surakarta.

Shuttleworth, Mark and Moiera Cowie. (1997). Dictionary of Translation Studies. Manchester: St. Jerome Publishing.

Suardana. (2010). Translation Procedures Of Biological Terms In Bilingual Biology 1 Students Text Book Year X.

Twain, M. (2007).Translated by Juniaring Zendrato dan Siwi Karmadi Jurniasih, Petualangan Huckleberry Finn. Yogyakarta: Narasi

Walinski. (2015). Translation Procedures, University of Lodz.

W. Brislin, Richard. (1976) Translation Application and Research, Gardner Press, INC., New Work.Distributed by Halsted Press, A division of JOHN WILEY AND SONS, INC 